\title{
Sebaran Sampah Pantai di Pulau Timor, Nusa Tenggara Timur: Kajian pada Pantai Rekreasi
}

\author{
The Distribution of Beach Debris in Timor Island, East Nusa Tenggara: \\ An Assessment of Recreational Beach
}

\author{
Lumban Nauli Lumban Toruan 1 \\ Program Studi Manajemen Sumberdaya Perairan, Fakultas Kelautan dan Perikanan \\ Universitas Nusa Cendana, Kupang, Indonesia
}

\section{Ismawan Tallo}

Program Studi Manajemen Sumberdaya Perairan, Fakultas Kelautan dan Perikanan Universitas Nusa Cendana, Kupang, Indonesia

\section{Suprabadevi Ayumayasari Saraswati}

Program Studi Manajemen Sumberdaya Perairan, Fakultas Kelautan dan Perikanan Universitas Nusa Cendana, Kupang, Indonesia

Artikel Masuk : 23 Desember 2020

Artikel Diterima : 20 April 2021

Tersedia Online : 30 April 2021

\begin{abstract}
Abstrak: Sampah pesisir merupakan masalah yang semakin penting untuk dikaji mengingat dampak negatifnya bagi lingkungan daratan dan lautan. Tujuan penelitian ini untuk mengkaji sebaran sampah pantai di Pulau Timor sebagai salah satu dasar pengambilan kebijakan dalam pengelolaan dan mengatasi cemaran sampah. Penelitian dilakukan pada Bulan Agustus 2020 di enam pantai wisata yang dikelola oleh pemerintah, yaitu satu di Kota Kupang dan lima kabupaten (Malaka, Timor Tengah Selatan, Kupang, Timor Tengah Utara, dan Belu). Pada setiap lokasi dibuat transek sepanjang 100 meter sejajar garis pantai dengan lebar transek sepanjang $10 \mathrm{~m}$ tegak lurus garis pantai yang diukur dari bagian belakang pantai. Seluruh sampah dalam transek diambil, lalu dibersihkan dari pasir, kemudian dimasukkan ke dalam kantong plastik yang telah diberi label. Sampah yang basah dijemur sampai kering sebelum dihitung. Sampah kemudian dipilah, lalu dihitung jumlah, panjang, dan beratnya. Hasil penelitian menunjukkan seluruh pantai telah terpapar oleh sampah yang tidak terkelola. Sampah plastik mendominasi seluruh lokasi dengan komposisi jumlah antara 63 - 95\% (rerata $80 \pm 12 \%$ ) dan panjang antara 60 - 93\% (rerata $75 \pm 13 \%$ ). Komposisi berat sampah plastik antara $20-72 \%$ (rerata $45 \pm 21 \%$ ), dan berat sampah plastik tidak mendominasi pada Pantai Motadikin. Dinamika arus laut pada muson timur diduga berperan dalam menyebabkan lebih rendahnya kuantifikasi sampah pada Pantai Motadikin (Kabupaten Malaka) dan Pantai Oetune (Kabupaten Timor Tengah Selatan) dibandingkan keempat pantai lainnya yang terletak di utara Pulau Timor. Sumber sampah pada pantai berasal dari kegiatan rekreasi, aktivitas nelayan dan berlabuh, serta sampah antropogenik yang terbawa dari laut.
\end{abstract}

Kata Kunci: pantai Pulau Timor; plastik; rekreasi; sampah

\footnotetext{
${ }^{1}$ Korespondensi Penulis: Program Studi Manajemen Sumberdaya Perairan, Fakultas Kelautan dan Perikanan Universitas Nusa Cendana, Kupang, Indonesia

Email: lumbannauli@staf.undana.ac.id
} 


\title{
93 Sebaran Sampah Pantai di Pulau Timor, Nusa Tenggara Timur ...
}

\begin{abstract}
Beach debris is an increasingly important issue to study considering its negative impact on the terrestrial and marine environment. This research aims to examine the distribution of beach debris in Timor Island as a basis for managing and overcoming waste pollution. The research was conducted in August 2020 on six government-managed tourism beaches consisting of one city (Kupang) and five regencies (Malaka, Timor Tengah Selatan, Kupang, Timor Tengah Utara, and Belu). At each location, a transect of 100 meters was made parallel to the shoreline with a transect width of $10 \mathrm{~m}$ perpendicular to the shoreline measured from the back of the beach. All trash in the transect was taken, then cleaned from the sand, then put in plastic bags that have been labeled. The wet litter was sun-dried before being counted. All waste was then sorted, then counted in the amount of item, weight, and length. The results showed that the entire beach had been exposed to unmanaged waste. Plastic waste dominates the entire site with a composition of numbers of items between 63 $95 \%$ (average $80 \pm 12 \%$ ) and length between $60-93 \%$ (average $75 \pm 13 \%$ ). The composition of the weight of plastic waste is between $20-72 \%$ (average $45 \pm 21 \%$ ), where the weight of plastic waste does not dominate at Motadikin Beach. The dynamics of ocean currents in the eastern monsoon are thought to have played a role in causing lower debris quantification at the Motadikin Beach (Malaka Regency) and Oetune Beach (Timor Tengah Selatan Regency) than to the other four beaches located in the north of Timor Island. The source of beach debris comes from recreational activities, fishing and anchoring activities, and anthropogenic waste carried away from the sea.
\end{abstract}

Keywords: litter; plastic; recreation; Timor Island beach

\section{Pendahuluan}

Sampah di pesisir merupakan salah satu masalah global yang makin krusial untuk ditangani. Keberadaan sampah memberikan pengaruh yang sensitif terhadap pembangunan suatu wilayah (Supardi et al., 2017). Berbagai rencana, kebijakan, peraturan, bahkan beragam aksi berkaitan dengan pengelolaan, kegiatan pembersihan, dan pemanfaatan sampah telah dikeluarkan berbagai lembaga agar jumlah serta penyebaran sampah dapat dikendalikan. Hadirnya Undang-Undang (UU) No. 18 Tahun 2008 tentang Pengelolaan Sampah (Pemerintah Republik Indonesia, 2008) sampai Peraturan Presiden (Perpres) Nomor 97 Tahun 2017 tentang Kebijakan dan Strategi Nasional Pengelolaan Sampah Rumah Tangga dan Sampah Sejenis Sampah Rumah Tangga (Peraturan Presiden Republik Indonesia, 2017) menunjukkan upaya yang kuat dari pemerintah pusat untuk mengendalikan sampah beserta dampak negatifnya. Berbagai kebijakan ini ditetapkan agar target pemerintah Indonesia untuk program reduce, reuse, dan recycle (3R) sebesar $30 \%$ sampai tahun 2025 dan pengurangan sampah plastik dari laut sebesar 70\% sampai dengan tahun 2025 dapat tercapai (KLHK, 2017). Hal ini dilakukan agar keberadaan sampah tidak sampai mengakibatkan dampak negatif terhadap estetika dan sanitasi lingkungan, keseimbangan ekosistem, maupun eksistensi mahluk hidup di sekitarnya.

Penambahan populasi manusia di Indonesia yang pesat dengan bermacam-macam aktivitasnya saat ini mengakibatkan pengendalian sampah di pesisir makin sulit untuk ditangani. Kajian Jambeck et al. (2015) yang seringkali dijadikan rujukan oleh berbagai artikel menunjukkan bahwa Indonesia merupakan penghasil sampah terbesar kedua di dunia setelah Cina. Berbagai aktivitas manusia merupakan penyumbang utama sampah di dunia, termasuk dalam hal ini juga di wilayah pesisir, yang jumlah populasi manusianya cukup padat. Aktivitas di pasar, pemukiman, pelabuhan, bahkan lokasi wisata memberikan pengaruh terhadap meningkatnya sampah di pesisir. Peningkatan jumlah sampah di pantai saat ini mulai mengkhawatirkan, salah satunya plastik. Plastik tipis seperti tas plastik di lautan dapat terdegradasi selama 20-30 tahun, namun botol plastik bisa lebih lama dari 80 tahun (Cheshire et al., 2009). Proses - proses fisik seperti pemanasan matahari dan dinamika air dapat mempercepat proses degradasi plastik dari yang berukuran besar 
sehingga terfragmentasi menjadi berukuran kecil yang disebut sebagai mikroplastik (Kovač Viršek et al., 2016). Berbagai dampak negatif dari sampah di pesisir telah dilaporkan, seperti dampak mikroplastik terhadap penghambatan aktivitas konsumsi pada organisme laut yang mengkibatkan dapat menurunnya energi dari organisme tersebut (Mrowiec, 2017), sampah plastik yang merugikan usaha penangkapan ikan (Waileruny et al., 2019), dan juga dampak buruknya terhadap pariwisata (Jang et al., 2014; Krelling et al., 2017).

Kajian sampah pada pantai telah dilakukan di berbagai belahan dunia seperti di Teluk Persia bagian Utara (Sarafraz et al., 2016), Pesisir Timur Mediterania (Portman \& Brennan, 2017), Pesisir Utara Cornwall di Inggris (Watts et al., 2017), tenggara Laut Hitam (Aytan et al., 2019), dan Pesisir Santa Catarina Brazil (Marin et al., 2019). Hasil kajian menunjukkan plastik merupakan sampah yang mendominasi pesisir pantai. Beragam penelitian terkait sampah pada pantai di Indonesia pun telah dilakukan (Syakti et al., 2017), mulai dari bagian barat (Jati \& Utomo, 2020; Kusumawati et al., 2018; Willoughby, 1986) sampai timur (Evans et al., 1995; Sahar et al., 2020; Tuhumury \& Kaliky, 2019). Aktivitas antropogenik menjadi sumber utama produksi sampah pada pantai di Indonesia, terutama pada pantaipantai wisata, dengan limbah plastik mendominasi jenis sampah yang ditemukan. Dominasi sampah plastik pada seluruh jenis limbah anorganik ditemukan juga pada berbagai pengamatan di pesisir pantai Nusa Tenggara Timur, baik di Kabupaten Rote, Kabupaten Kupang, dan Kabupaten Flores Timur (Nawastuti \& Lewoema, 2019; Purba et al., 2018).

Kawasan Timor Barat pada Pulau Timor merupakan wilayah yang cukup padat. Rasio jumlah penduduk per luasan wilayah pada enam kabupaten kota di Pulau Timor ini lebih tinggi dibandingkan gabungan 16 kabupaten lainnya pada Provinsi Nusa Tenggara Timur (NTT), yaitu 136,6:106,3 penduduk/ $\mathrm{km}^{2}$ (BPS Provinsi Nusa Tenggara Timur, 2020). Kondisi ini tentunya memberikan potensi akumulasi sampah yang tinggi di pesisir Pulau Timor. Namun demikian, data mengenai sebaran sampah pantai masih sangat terbatas di pesisir ini. Purba et al. (2018) telah mendata sampah pantai di Pantai Oesina yang terletak di Kabupaten Kupang, sementara data mengenai kontribusi sampah pesisir di kota dan kabupaten lain di kawasan Pulau Timor belum tersedia. Menindaklanjuti program pemerintah yang tertuang dalam Perpres No.83 Tahun 2018 tentang Penanganan Sampah Laut dalam mengatasi pencemaran sampah di pesisir melalui penelitian berkesinambungan (Peraturan Presiden Republik Indonesia, 2018), maka data kondisi sampah pada pantai di Pulau Timor secara komprehensif perlu untuk disediakan dan dikaji. Penelitian ini dilakukan dengan tujuan untuk mengkaji sebaran sampah pantai di Pulau Timor sebagai salah satu dasar pengambilan kebijakan dalam pengelolaan dan mengatasi cemaran sampah. Kajian ini akan melengkapi secara komprehensif mengenai kondisi sampah pantai pada pesisir kabupaten dan kota yang terletak di Pulau Timor, Provinsi Nusa Tenggara Timur.

\section{Metode Penelitian}

\section{Kondisi Umum Lokasi}

Pulau Timor terletak di bagian selatan Indonesia, berbatasan dengan Negara Republik Democratik Timor Leste di bagian timur, Benua Australia di bagian selatan, Pulau Sumba di bagian barat, dan Pulau Flores di bagian utara. Kajian dilakukan pada enam pantai wisata yang dikelola oleh pemerintah di setiap wilayah administrasi. Pantai Motadikin terletak di Kabupaten Malaka, Pantai Oetune terletak di Kabupaten Timor Tengah Selatan (TTS), Pantai Tablolong di Kabupaten Kupang (Kab.Kpg), Pantai Lasiana di Kota Kupang (Kot.Kpg), Pantai Tanjung Bastian (Tj. Bastian) di Kabupaten Timor Tengah Utara (TTU), dan Pantai Pasir Putih di Kabupaten Belu (Gambar 1). Pantai Motadikin dan Pantai Oetune berada di bagian selatan Pulau Timor yang berhadapan dengan Samudera 
Hindia, Pantai Tablolong berada di bagian barat daya, sedangkan Pantai Lasiana, Pantai Tanjung Bastian, dan Pantai Pasir putih berada di bagian utara yang merupakan bagian dari wilayah Laut Sawu. Pantai Lasiana yang dikelola oleh Dinas Pariwisata Provinsi NTT terletak di areal Teluk Kupang. Pantai Tablolong dan Pantai Lasiana selain digunakan untuk aktivitas pariwisata, juga digunakan sebagai tempat berlabuh perahu nelayan. Kegiatan berlabuh pada Pantai Motadikin cukup jauh dari lokasi wisata dibandingkan kedua pantai sebelumnya. Gambaran umum lokasi penelitian secara ringkas disajikan dalam Tabel 1.

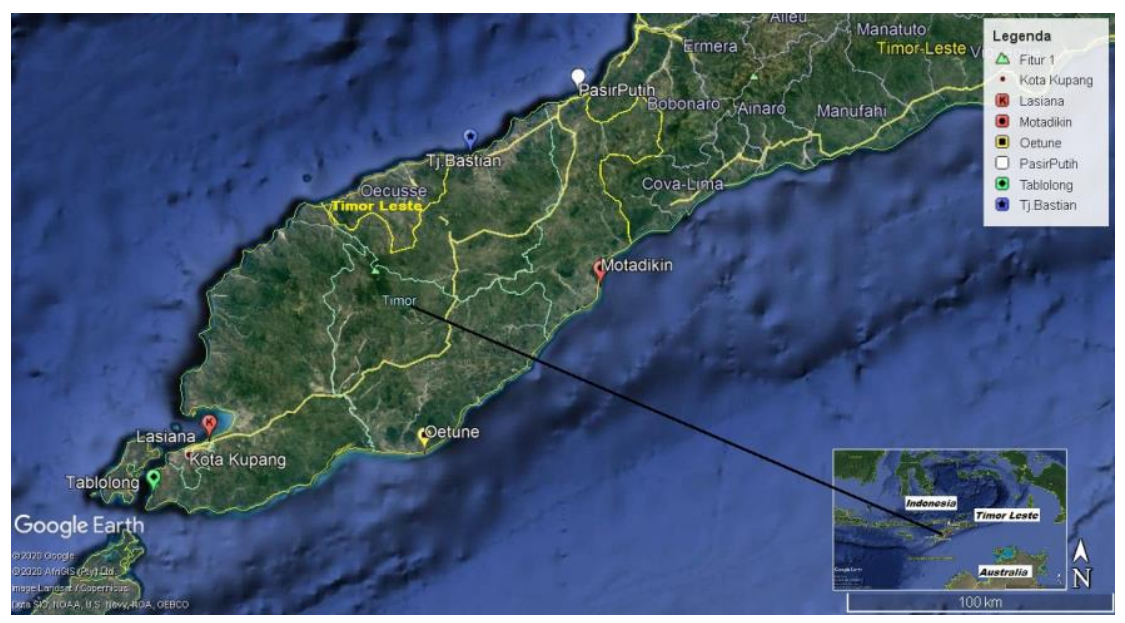

Gambar 1. Lokasi Penelitian

\section{Metode Pengambilan Contoh}

Pengambilan sampel dilakukan pada Bulan Agustus 2020. Pada Bulan Agustus merupakan musim timur, dan angin pada musim timur bergerak dari Benua Australia menuju Benua Asia. Sampling di Pantai Motadikin dilakukan pada tanggal 20, di Pantai Oetune pada tanggal 23, di Pantai Tablolong pada tanggal 4, di Pantai Lasiana pada tanggal 31, di Pantai Tanjung Bastian pada tanggal 11, dan di Pantai Pasir Putih pada tanggal 18.

Pengambilan sampah pada pantai serta proses identifikasi ke dalam sembilan kategori mengacu pada Cheshire et al. (2009). Metode ini telah diadaptasi menjadi panduan dalam berbagai pemantauan limbah di pantai oleh Kementerian Lingkungan Hidup dan Kehutanan (Kato et al., 2019). Penelitian ini melibatkan lima orang mahasiswa dalam melakukan pengambilan dan pemilahan sampah. Pengumpulan data di setiap pantai memerlukan waktu antara 1-2 jam tergantung banyaknya sampah.

Pada setiap lokasi dibuat transek sepanjang $100 \mathrm{~m}$ sejajar garis pantai dengan lebar transek sepanjang $10 \mathrm{~m}$ tegak lurus garis pantai yang diukur dari bagian belakang pantai. Penentuan bagian belakang pantai dilakukan dengan memperhatikan keberadaan vegetasi, gundukan, jalan, perumahan, atau struktur buatan. Penjaminan akurasi dalam pengambilan sampah dilakukan dengan membagi setiap bagian lebar menjadi tiap satu meter menggunakan dua paralon berdiameter setengah dim. Setiap pipa berukuran panjang satu meter dan satu bagian pipa dililit tali tambang sepanjang $100 \mathrm{~m}$. Bagian pipa yang tidak dililit dipatok di sedimen mengunakan patok atau batu, sedangkan bagian yang dililit tambang ditarik oleh setiap mahasiswa. Setiap mahasiswa yang memegang paralon tersebut akan berjalan beriringan sejauh $100 \mathrm{~m}$ sejajar pantai sambil menarik dan meletakkan tali tambang yang telah dililitkan pada pipa paralon tersebut. Setelah itu setiap orang akan mengambil sampah dari setiap jalur di antara dua tali tambang, lalu 
membersihkannya dari pasir, kemudian memasukkannya dalam kantong plastik yang telah diberi label (Gambar 2).

Tabel 1. Gambaran Umum Lokasi Penelitian

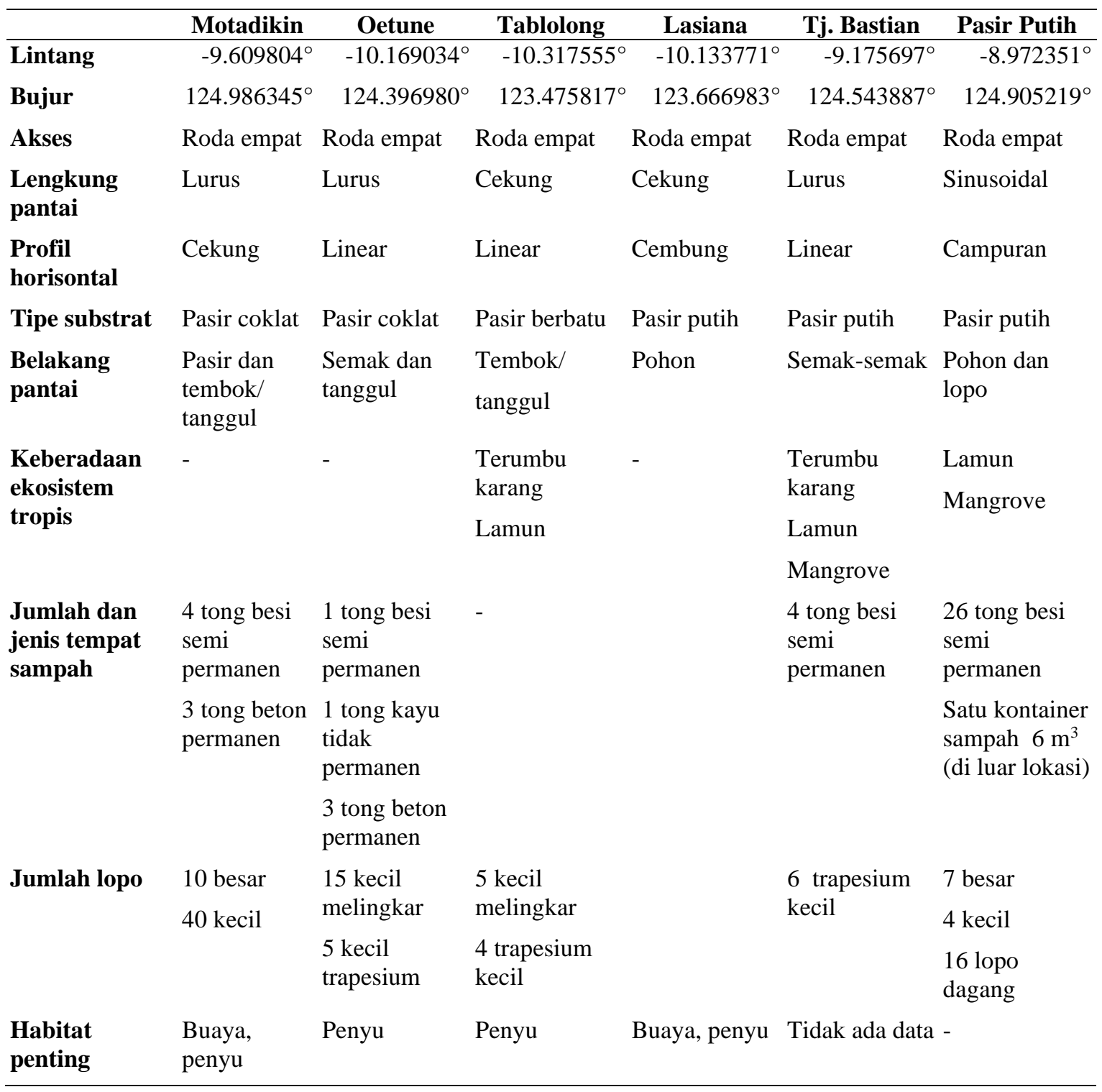

Perekaman koordinat lokasi menggunakan aplikasi android yaitu Global Positioning System (GPS) Map Camera Versi 1.1.3. Gambar yang menunjukkan lokasi penelitian diambil melalui aplikasi GPS saat telah muncul lambang lokasi berwarna merah pada inset di bagian kiri bawah aplikasi agar menjamin akurasi lokasi. Aplikasi GPS ini membutuhkan jaringan internet dalam penggunaannya.

Sebelum pemilahan, sampah yang basah seperti kain dijemur sampai kering. Keseluruhan sampah lalu dipilah berdasarkan sembilan kategori, yaitu plastik, gabus, kain, gelas dan keramik, logam, kertas, karet, kayu, dan benda lainnya yang merupakan bahan campuran. Pada setiap kategori dibagi lagi menjadi subkategori lalu dihitung total jumlah, panjang, dan berat sampahnya. 


\section{Sebaran Sampah Pantai di Pulau Timor, Nusa Tenggara Timur ..}

\section{Analisis Statistik}

Analisis deskriptif berupa jumlah, panjang, dan berat sampah per luasan, rerata keseluruhan sampel sampah, dan kontribusi jenis sampah dibandingkan total keseluruhan sampah yang dihitung sebagai komposisi dilakukan untuk menganalisis sampah (Schulz et al., 2017). Data disajikan dalam nilai rata-rata \pm standar deviasi (Syakti et al., 2017). Penulisan panjang, jumlah, dan berat mengacu pada luasan $1.000 \mathrm{~m}^{2}$ sesuai dengan panjang $(100 \mathrm{~m})$ dan lebar $(10 \mathrm{~m})$ yang dibuat di setiap lokasi, sehingga semua data merupakan akumulasi dari luasan $1.000 \mathrm{~m}^{2}$. Hubungan antara jumlah dan panjang, berat dan panjang, serta jumlah dan berat dikalkulasi menggunakan analisis korelasi. Seluruh proses perhitungan dan penyajian grafik menggunakan perangkat lunak MS Excel 2007.

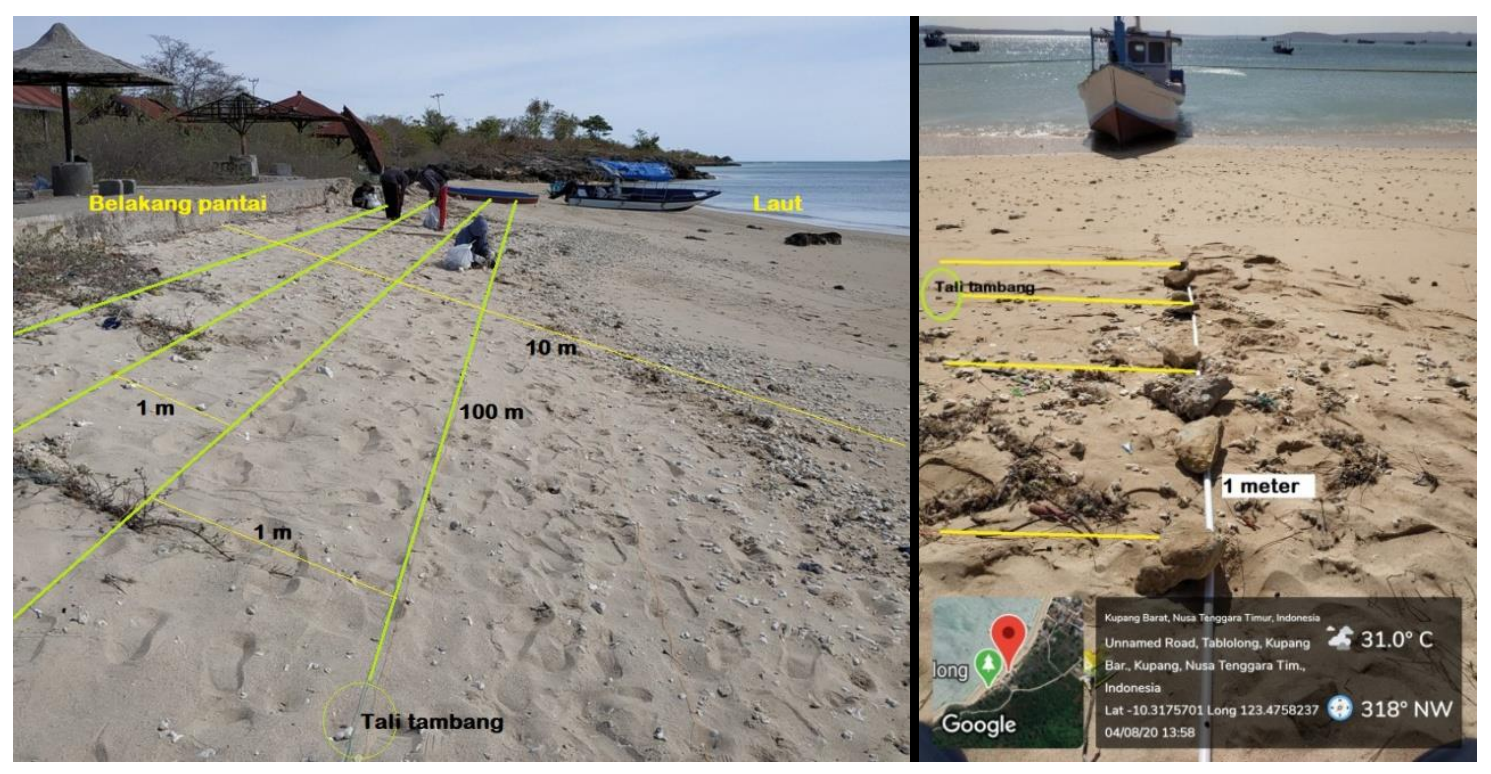

Gambar 2. Ilustrasi Pengambilan Sampel

\section{Hasil dan Pembahasan}

Hasil

Tiga kategori pada komposisi sampah terbesar di seluruh pantai adalah kategori plastik, kain dan logam. Ketiga kategori tersebut memberikan kontribusi sebanyak 90,7\% pada kategori jumlah, 68,8\% pada berat, dan 92,1\% pada panjang. Kategori plastik mendominasi rerata komposisi sampah di semua pantai (Gambar 3) baik dari total jumlah $(79,7 \%$; rerata $=926,7 \pm 587,2$ potongan), total berat $(44,7 \%$; rerata $=2,56 \pm 1,44 \mathrm{~kg})$, dan total panjang $(74,6 \%$; rerata $=135,5 \pm 103,9 \mathrm{~m})$.

Pantai Tablolong menunjukkan komposisi sampah terbesar dari seluruh pantai (Gambar 4), diikuti oleh Pantai Pasir Putih dan Pantai Tanjung Bastian pada komposisi jumlah, serta Pantai Lasiana dan Pantai Tanjung Bastian pada komposisi berat dan panjang. Selaras dengan banyaknya sampah plastik di Tablolong, kuantifikasi pada kategori yang lain pun cenderung lebih tinggi dibandingkan pantai lainnya. Hal ini menyebabkan baik jumlah potongan, berat, dan panjang sampah di Tablolong merupakan yang tertinggi dibandingkan lokasi lainnya (Gambar 5). Jumlah potongan, berat, dan panjang sampah pada Pantai Motadikin dan Pantai Oetune yang berada di bagian selatan Pulau Timor lebih rendah dibandingkan empat pantai kajian yang berada di bagian utara Pulau Timor. 
Hubungan total jumlah dan panjang sampah menunjukkan korelasi yang sangat kuat $(\mathrm{r}=0,94 ; \mathrm{n}=6)$ dibandingkan berat-panjang $(\mathrm{r}=0,93 ; \mathrm{n}=6)$ dan jumlah-berat $(\mathrm{r}=0,79 ; \mathrm{n}=$ 6). Hubungan tersebut tercermin juga pada sampah plastik yang korelasi antara jumlah dan panjang plastik $(\mathrm{r}=0,88 ; \mathrm{n}=6)$ lebih kuat daripada korelasi antara berat dan panjang $(\mathrm{r}=$ 0,79; $n=6)$, sedangkan korelasi terendah adalah antara jumlah dan berat plastik $(r=0,65 ; n$ =6). Namun demikian, secara umum nilai korelasi ini menunjukkan adanya hubungan yang positif antara jumlah, berat, dan panjang sampah.
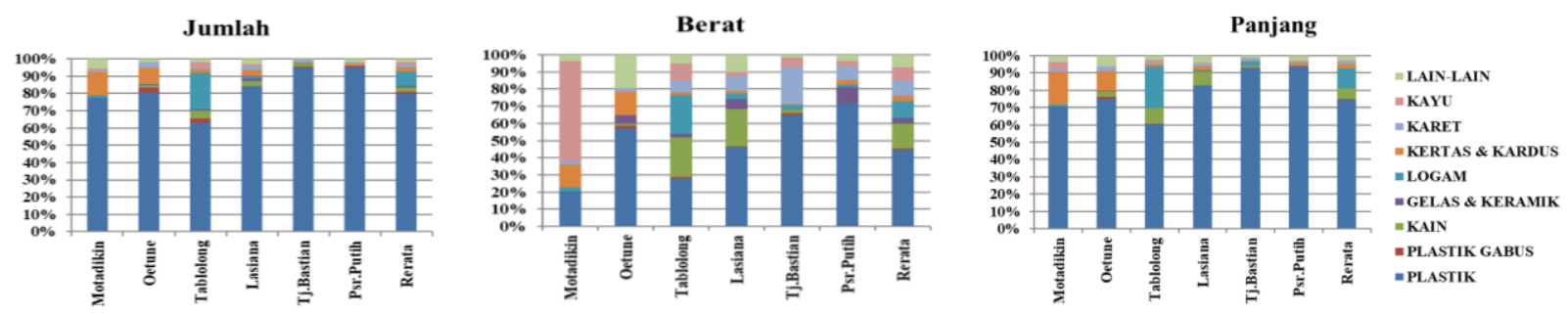

\section{Gambar 3. Komposisi Jumlah, Berat, dan Panjang Sampah Pantai Berdasarkan Kategori}
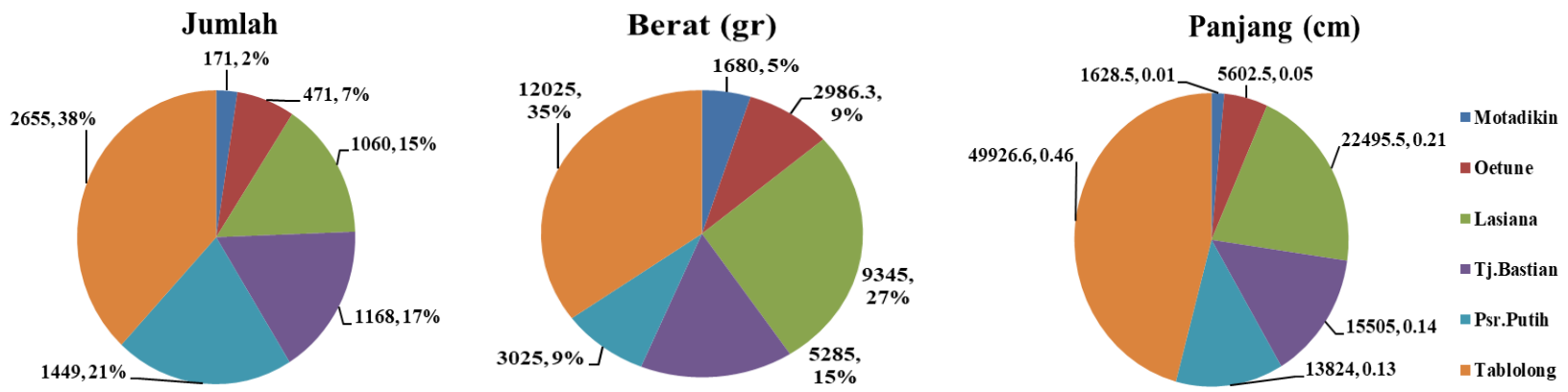

Gambar 4. Komposisi Jumlah, Berat, dan Panjang Sampah Berdasarkan Lokasi
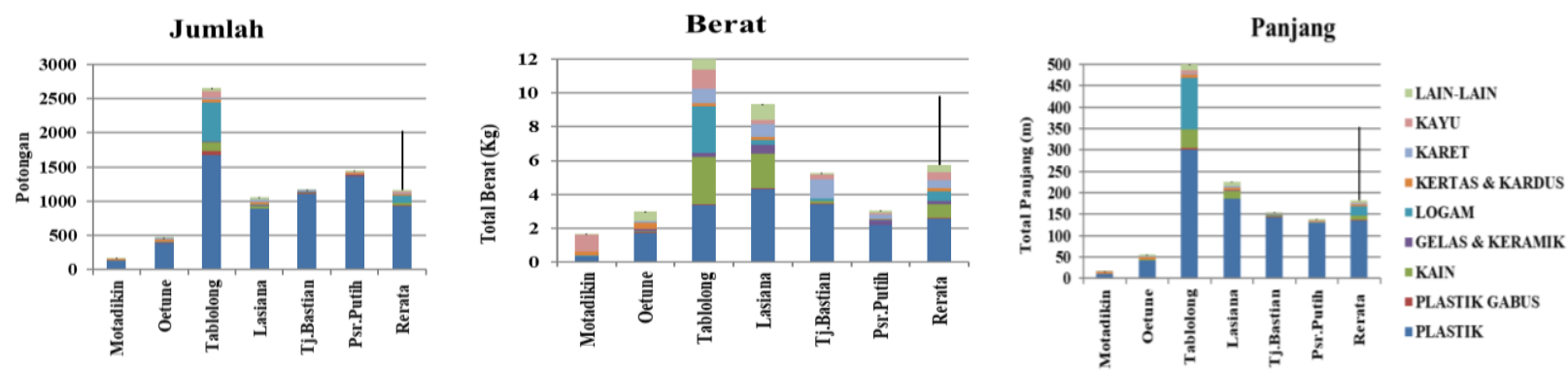

\section{Gambar 5. Jumlah, Berat, dan Panjang Sampah Pantai}

Tabel 2 menyajikan perbandingan jumlah potongan dan berat sampah antara hasil kajian ini dengan studi lain yang dilakukan di berbagai wilayah di Indonesia pada musim yang cenderung tidak berbeda jauh selangnya. Secara umum persentase sampah plastik yang ditemukan dari seluruh lokasi adalah $73,5 \%$. Nilai ini lebih rendah dari persentase sampah yang umumnya ditemukan di Pulau Timor. 
Tabel 2. Perbandingan Jumlah dan Berat Sampah serta Persentase Jumlah Sampah Plastik yang Ditemukan pada Kajian Ini dengan Kajian Lainnya di Berbagai Wilayah di Indonesia

\begin{tabular}{|c|c|c|c|c|c|c|}
\hline $\begin{array}{c}\text { Lokasi } \\
\text { (Pantai, Kab./Kot.- } \\
\text { Prov.) }\end{array}$ & Bulan & $\begin{array}{c}\text { Jumlah } \\
\text { (potongan } \\
\left./ \mathbf{m}^{2}\right)\end{array}$ & $\begin{array}{l}\text { Berat } \\
\left(\mathrm{gr} / \mathrm{m}^{2}\right)\end{array}$ & $\begin{array}{l}\text { Persentase } \\
\text { Jumlah } \\
\text { Sampah } \\
\text { Plastik }\end{array}$ & Pemanfaatan & Pustaka \\
\hline $\begin{array}{l}\text { Motadikin, Kab. } \\
\text { Malaka-NTT }\end{array}$ & Juli & 0,17 & 1,7 & 77,2 & Wisata & Kajian ini \\
\hline Oetune, Kab. TTS-NTT & & 0,47 & 3,0 & 80,7 & Wisata & \\
\hline $\begin{array}{l}\text { Tablolong, Kab.Kupang- } \\
\text { NTT }\end{array}$ & & 2,66 & 12,0 & 63,2 & Wisata & \\
\hline $\begin{array}{l}\text { Lasiana, Kot. Kupang- } \\
\text { NTT }\end{array}$ & & 1,06 & 9,4 & 84,2 & Wisata & \\
\hline $\begin{array}{l}\text { Tj.Bastian, Kab.TTU- } \\
\text { NTT }\end{array}$ & & 1,17 & 5,3 & 94,9 & Wisata & \\
\hline $\begin{array}{l}\text { Pasir Putih, Kab. Belu- } \\
\text { NTT }\end{array}$ & & 1,45 & 3,0 & 94,5 & Wisata & \\
\hline $\begin{array}{l}\text { Oesina, Kab. Kupang- } \\
\text { NTT }\end{array}$ & Juni & 3,23 & 150,0 & 78,9 & Wisata & $\begin{array}{l}\text { (Purba et al., } \\
2018 \text { ) }\end{array}$ \\
\hline Oeseli , Kab. Rote-NTT & & 4,10 & 110,0 & 55,8 & $\begin{array}{l}\text { Wisata dan } \\
\text { budidaya }\end{array}$ & \\
\hline $\begin{array}{l}\text { Nembrala, Kab. Rote- } \\
\text { NTT }\end{array}$ & & 3,24 & 40,0 & 57.9 & $\begin{array}{l}\text { Wisata dan } \\
\text { pemukiman }\end{array}$ & \\
\hline $\begin{array}{l}\text { Tiang Bendera, Kab. } \\
\text { Rote-NTT }\end{array}$ & & 7,99 & 110,0 & 60,7 & Wisata & \\
\hline $\begin{array}{l}\text { Pesisir Aceh Barat, Kab. } \\
\text { Aceh Barat-Aceh }\end{array}$ & $\begin{array}{l}\text { Agustus- } \\
\text { September }\end{array}$ & - & - & 71.4 & Wisata & $\begin{array}{l}\text { (Kusumawati et } \\
\text { al., 2018) }\end{array}$ \\
\hline $\begin{array}{l}\text { Ekowisata Mangrove } \\
\text { Kampung Mengkapan, } \\
\text { Kab. Siak- Riau }\end{array}$ & Juni-Juli & - & - & 80,5 & Wisata & $\begin{array}{l}\text { (Silmarita et al., } \\
\text { 2019) }\end{array}$ \\
\hline $\begin{array}{l}\text { Ekosistem Mangrove } \\
\text { Kampung Sungai Rawa, } \\
\text { Kab.Siak-Riau }\end{array}$ & Juni-Juli & 4,25 & 540,0 & 69,3 & $\begin{array}{l}\text { Pemukiman } \\
\text { dan berlabuh }\end{array}$ & $\begin{array}{l}\text { (Fajriah et al., } \\
\text { 2019) }\end{array}$ \\
\hline $\begin{array}{l}\text { Peunaga Permai, Kab. } \\
\text { Nagan Raya-Aceh }\end{array}$ & Juli & - & - & 67,0 & Wisata & $\begin{array}{l}\text { (Kusumawati et } \\
\text { al., 2019) }\end{array}$ \\
\hline $\begin{array}{l}\text { Tanjung Bayang, } \\
\text { Akkarena, } \\
\text { Lae-Lae, } \\
\text { Kot.Makassar- Sulawesi } \\
\text { Selatan }\end{array}$ & $\begin{array}{l}\text { Agustus- } \\
\text { Oktober }\end{array}$ & $\begin{array}{l}0,38 \\
0,07 \\
0,49\end{array}$ & $\begin{array}{l}6,1 \\
3,0 \\
9,6\end{array}$ & $\begin{array}{l}61,3 \\
72,0 \\
67,0\end{array}$ & Wisata & $\begin{array}{l}\text { (Tahir et al., } \\
\text { 2019) }\end{array}$ \\
\hline $\begin{array}{l}\text { Batu Payung, Kab. } \\
\text { Bengkayang }\end{array}$ & Juli & 5,68 & 62,5 & 88,0 & $\begin{array}{l}\text { Wisata dan } \\
\text { pemukiman }\end{array}$ & $\begin{array}{l}\text { (Jati \& Utomo, } \\
\text { 2020) }\end{array}$ \\
\hline $\begin{array}{l}\text { Pasir Panjang, Kot. } \\
\text { Singkawang. } \\
\text {-Kalimantan Barat }\end{array}$ & & 11,08 & 19,2 & 89,5 & & \\
\hline $\begin{array}{l}\text { Kuri, Kab.Maros- } \\
\text { Sulawesi Selatan }\end{array}$ & $\begin{array}{l}\text { Agustus- } \\
\text { September }\end{array}$ & - & - & 55,0 & Wisata & $\begin{array}{l}\text { (Sahar et al., } \\
\text { 2020) }\end{array}$ \\
\hline RERATA+St.Dev & & $\begin{array}{r}2,97 \pm \\
3,12\end{array}$ & $\begin{array}{r}67,8 \pm \\
134,4\end{array}$ & $\begin{array}{r}73,5 \pm \\
12,7\end{array}$ & & \\
\hline
\end{tabular}


Ukuran sampah yang ditemukan umumnya termasuk dalam kategori sampah makro (makro debris) (Gambar 6). Pada Tanjung Bastian terdapat sampah mega debris pada kategori logam, dimana terdapat dua potong kawat dengan panjang total mencapai 340 $\mathrm{cm}$. Hal ini yang memengaruhi deviasi yang tinggi pada kategori logam (rerata $=28,8 \pm$ 46,8 cm). Berbeda dengan rasio panjang/jumlah, maka pada rasio berat/jumlah (Gambar 7), deviasi tertinggi ada pada kategori kayu (rerata $=116,7 \pm 190,6$ gr) akibat ditemukannya kayu hasil aktivitas pariwisata berupa plang nama di Pantai Motadikin. Sampah plastik menunjukkan berat terendah dengan standar deviasi terendah juga (rerata $=3,1 \pm 1,3$ gr). Hal ini menunjukkan bahwa berat sampah plastik di setiap lokasi cenderung tidak berbeda. Pantai Pasir Putih secara umum menunjukkan rerata rasio panjang/jumlah $(9,8 \pm 5,9 \mathrm{~cm})$ dan rasio berat/jumlah $(11,1 \pm 11,7 \mathrm{gr})$ terendah dibandingkan pantai lainnya.

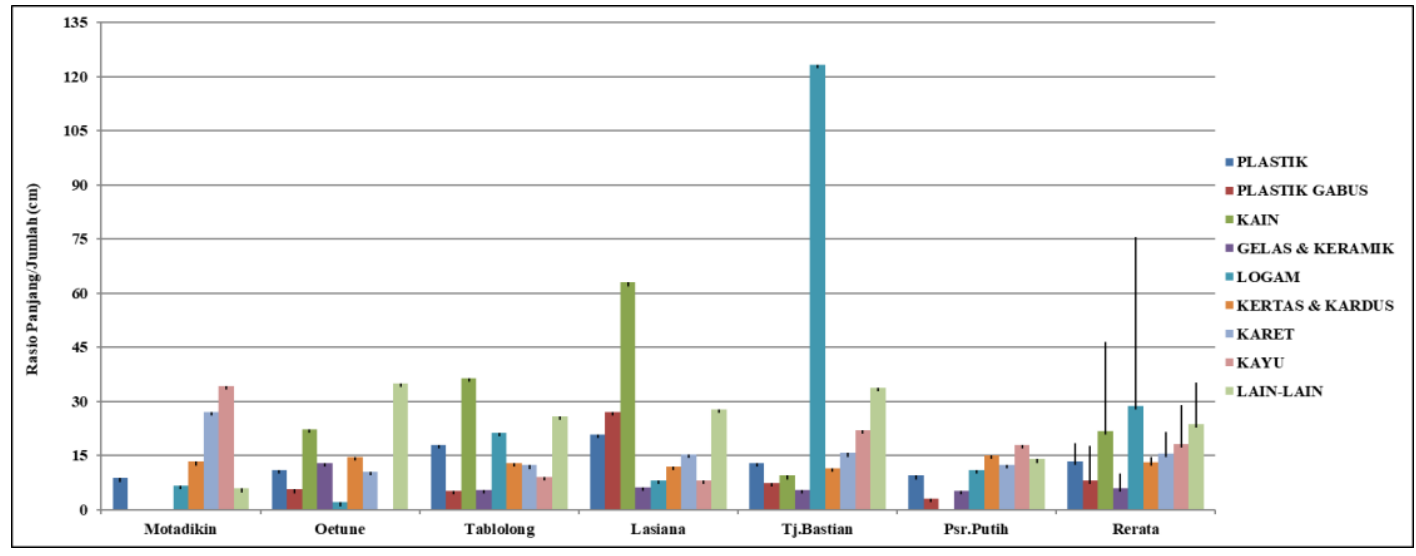

Gambar 6. Rasio Panjang/Jumlah (cm)

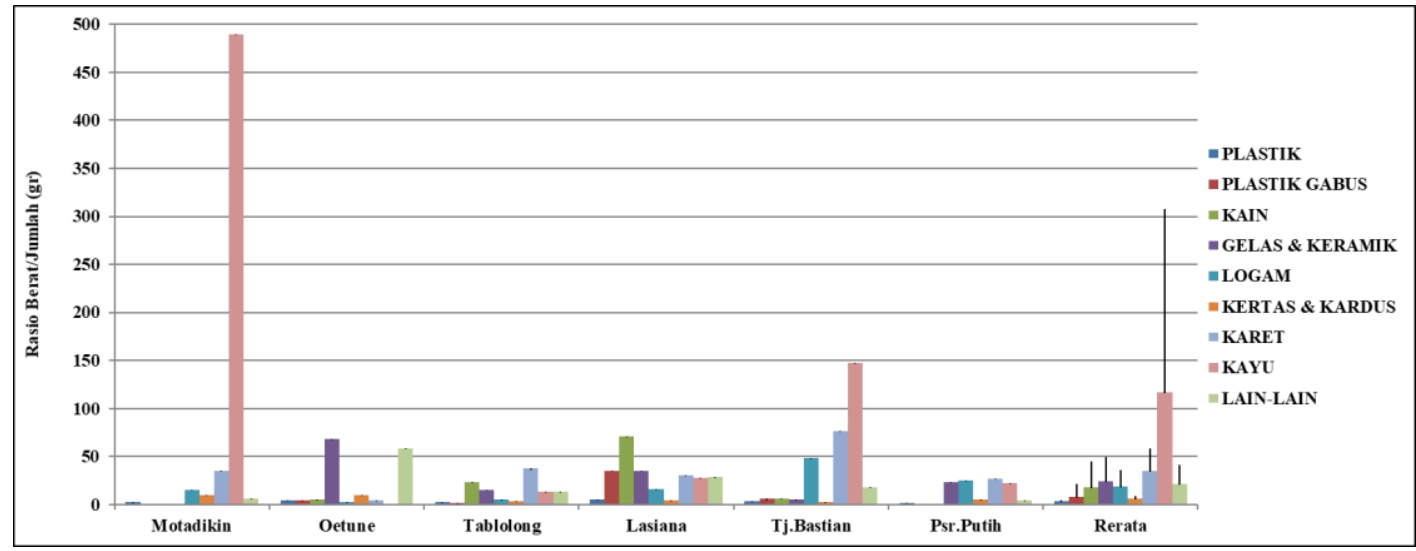

Gambar 7. Rasio Berat/Jumlah (cm)

Tabel 3 secara khusus menyajikan 11 subkategori dari sembilan kategori sampah plastik. Perlengkapan makanan dan minuman merupakan sampah plastik yang sering ditemukan. Wadah plastik pembungkus makanan yang diperoleh seperti bungkus kacang dan jagung goreng, plastik mika, bungkus mie instan, bungkus permen, sedangkan alat makanan seperti sendok, garpu, serta sedotan. Serpihan plastik juga sangat umum ditemukan di seluruh lokasi. Serpihan ini berupa potongan plastik yang tidak dapat diidentifikasi lagi kategorinya. 


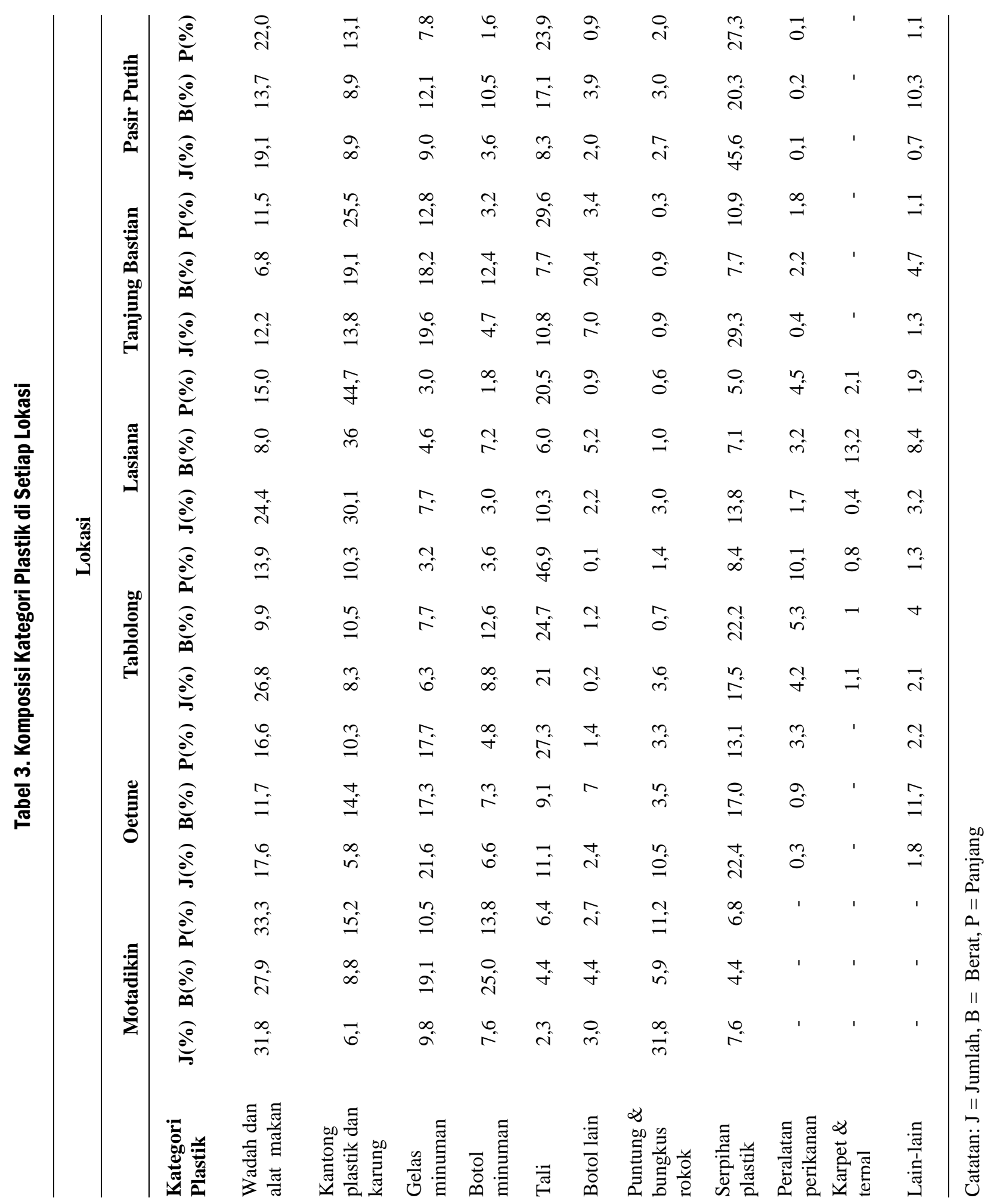




\section{Pembahasan}

Seluruh pantai yang diobservasi merupakan pantai yang dirancang dan dikelola oleh pemerintah dengan tujuan utama wisata/rekreasi. Pada Pantai Tablolong (Kabupaten Kupang) dan Pantai Lasiana (Kota Kupang) sebagian wilayah pantainya digunakan juga sebagai tempat berlabuh. Banyaknya jumlah tali yang dipadukan dengan banyaknya sampah plastik peralatan yang berhubungan dengan kegiatan perikanan seperti jaring mengindikasikan cukup tingginya intensitas penggunaan kedua pantai ini dalam kegiatan perikanan. Hal lain yang menunjukkan kedua pantai ini sebagai tempat berlabuh adalah keberadaan sampah logam berupa kawat, kaitan, kaleng bekas cat yang biasanya digunakan untuk melapisi kayu perahu, dan berbagai serpihan logam. Letak Lasiana yang berada pada Kota Kupang yang padat populasinya dan posisi Pantai Tablolong yang tidak terlalu jauh dengan waktu tempuh sekitar satu jam dari pusat Kota Kupang mengakibatkan kunjungan wisatawan ke dua lokasi ini lebih banyak. Laporan Badan Pusat Statistik Provinsi Nusa Tenggara Timur (2020) menunjukkan kepadatan populasi Kota Kupang pada tahun 2019 merupakan yang tertinggi di Provinsi NTT, yaitu 2.413 orang $/ \mathrm{km}^{2}$. Sementara itu pada tahun yang sama, di kabupaten lainnya di Pulau Timor berkisar antara 73-176 orang $/ \mathrm{km}^{2}$. Tentunya intensitas rekreasi ini berbanding lurus terhadap timbulan sampah ditambah tidak adanya tempat sampah yang memadai pada kedua pantai yang berhadapan dengan laut ini. Pada Pantai Lasiana, tempat sampah umumnya berada di belakang struktur beton sebagai pembatas pantai dengan lopo dan tempat berjualan.

Hasil dari penelitian ini sejalan dengan berbagai kajian yang telah dilakukan di Indonesia (Tabel 2), dimana plastik mendominasi sampah di wilayah pesisir. Meskipun jumlah potongan dan berat sampah pada keenam pantai yang dikaji cenderung lebih rendah dari pantai lainnya di Indonesia, kecuali dibandingkan dengan Kota Makassar (Tahir et al., 2019), namun persentase sampah plastik yang didapatkan umumnya lebih tinggi dibandingkan kajian yang pernah dilakukan oleh berbagai peneliti lainnya. Tingginya sampah kategori plastik menunjukkan ketergantungan masyarakat, khususnya wisatawan lokal terhadap penggunaan berbagai macam material yang menggunakan dan atau berbahan plastik. Ciri khas penggunaan pantai rekreasi terlihat dari banyaknya sampah plastik yang digunakan sebagai perlengkapan makanan dan minuman. Kategori ini pun sangat sering ditemukan dengan jumlah yang banyak di berbagai pantai rekreasi di Indonesia pada berbagai musim, seperti di Bali (Attamimi et al., 2015), Banten (Maharani et al., 2018), Kupang dan Rote (Purba et al., 2018), Minahasa (Bangun et al., 2019), dan belahan bumi lainnya seperti pada pantai di Laut Hitam (Aytan et al., 2019). Puntung rokok yang ditemukan dalam kajian ini telah diusulkan sebagai indikator tingginya intensitas pemanfaatan ruang pantai oleh manusia (Araújo et al., 2018), meski demikian harus dilakukan kajian lebih luas untuk menentukan apakah usulan ini bersifat universal, terutama untuk pantai yang peruntukannya sebagai area wisata, mengingat aktivitas konsumsi makanan dan minuman di areal wisata di lokasi kajian lebih umum ditemukan dibandingkan aktivitas merokok.

Sumber utama sampah dari pantai tujuan wisata ini adalah dari daratan yang dilakukan oleh manusia, khususnya pengunjung pantai. Meskipun sudah disediakan tempat sampah hampir di semua lokasi (kecuai Pantai Tablolong), namun perilaku buruk dari pengunjung yang membuang sampah tidak pada tempatnya menyebabkan sampah seringkali berada di luar tempat sampah. Kebiasaan ini bahkan merupakan kontributor utama pada penumpukan sampah di pesisir (Kusumawati \& Setyowati, 2018). Selain itu, berdasarkan pengamatan, jumlah tempat sampah umumnya belum memadai dibandingkan dengan luasan pantai dan letaknya yang tidak strategis sesuai dengan jalur lintasan wisatawan. Kondisi ini merupakan hal umum yang terjadi di tempat rekreasi pantai di Indonesia (Shuker \& Cadman, 2018). Letak tempat sampah umumnya berada di bagian belakang pantai di antara lopo-lopo. Letak tempat sampah ini sebenarnya tidak jauh dari 
lintasan pengunjung di pantai, namun umumnya wisatawan yang tidak mau berlama-lama memegang sampah sampai menemukan tempat sampah akan langsung membuang sampahnya di pantai. Pada masa pandemi Covid-19 ini, ditemukan limbah berupa dua lembar masker medis pada Pantai Lasiana-Kota Kupang dan satu lembar di Pantai OetuneKabupaten Timor Tengah Selatan. Kedua pantai ini sangat ramai dikunjungi wisatawan baik dalam maupun lintas kabupaten/kota, bahkan pada Pantai Oetune banyak lahan yang sering dijadikan tempat menginap sampai berkemah. Temuan masker medis yang tidak lazim pada kondisi biasa ini ditemukan juga oleh Cordova et al. (2021) di Teluk Jakarta selama pandemi Covid-19 mewabah.

Penanganan sampah yang kurang layak oleh pengelola tempat wisata ikut menambah permasalahan estetika pantai karena sampah tidak dibawa ke Tempat Pemrosesan Akhir (TPA), padahal kebersihan area pantai merupakan salah satu faktor utama untuk kawasan pantai dengan tujuan wisata (Darmawi, 2017). Meskipun seluruh pantai ini dikelola oleh masing-masing pemerintah daerah, namun tidak semua pantai memiliki petugas kebersihan yang secara khusus membersihkan pantai secara regular dengan jumlah yang memadai. Sebagai contoh pada Pantai Pasir Putih di Kabupaten Belu terdapat satu orang tua yang bertugas membersihkan pantai. Keberadaan jumlah tempat sampah yang cukup banyak, kontainer sampah yang tepat berada di sisi luar batas Pantai Pasir Putih sebagai Tempat Penampungan Sementara (TPS), dan kehadiran petugas kebersihan membuat sampah yang berukuran cukup besar lebih mudah untuk dibersihkan dari pantai. Upaya ini memberikan dampak terhadap nilai dari rasio panjang/jumlah dan rasio berat/jumlah sampah yang terendah dari seluruh pantai yang dikaji, artinya sampah yang ditemukan umumnya berukuran kecil karena berupa potongan, sedangkan sampah berukuran besar dapat dibersihkan dari pantai. Mekipun secara rasio, Pantai Pasir putih merupakan yang terendah, namun pantai tersebut memiliki potongan sampah terbanyak kedua setelah Pantai Tablolong. Kondisi ini terjadi karena banyaknya serpihan sampah plastik yang tidak terangkut ke tempat sampah.

Berdasarkan hasil wawancara informal dengan masyarakat, selama ini kegiatan Jumat bersih yang diadakan pemerintah kurang dapat menggerakkan masyarakat bersamasama dengan pengelola untuk terlibat aktif melakukan kegiatan bersih pantai. Masyarakat cenderung membiarkan sampah di pantai dan menganggap percuma pantai dibersihkan karena ada musim yang membuat pantai menjadi kotor dan ada musim yang membuat pantai menjadi bersih. Masyarakat setempat berpendapat bahwa pada musim barat pantai biasanya kotor karena dua hal, yaitu: (1) saat musim hujan, air dari sungai akan membawa sampah ke arah lautan, lalu arus laut akan membawanya ke arah pantai, sampah ini umumnya berupa sampah organik seperti potongan kayu dan ranting, serta buah, khususnya buah kelapa dan (2) adanya sampah lain yang dibawa oleh arus lautan ke arah pantai, umumnya yang terdampar berupa sampah anorganik. Pada musim timur pantai akan bersih dengan sendirinya karena sampahnya dibawa oleh angin dan arus ke arah laut, hal ini khususnya terjadi di bagian selatan Pulau Timor dan sungai-sungai umumnya dalam keadaan kering akibat tidak ada hujan, sehingga tidak ada sampah yang dibawa ke arah laut melalui sungai. Pandangan masyarakat mengenai pergerakan sampah ini sesuai dengan kajian Prevenios et al. (2018), yaitu arus lautan dapat memindahkan sampah dari satu lokasi tersebar ke lokasi lainnya, sehingga jumlah sampah pada setiap lokasi bisa berubah tergantung perubahan musim yang dapat menyebabkan perubahan pada arah arus (Ribic et al., 2012). Apabila sampah sudah menumpuk, umumnya sampah dibakar di lubang-lubang pasir yang dibuat di sekitar pantai atau dibakar di tong sampah baik oleh petugas atau pengunjung. Proses pembakaran sampah seringkali tidak sempurna, sehingga banyak menimbulkan serpihan sampah yang dapat terbawa oleh angin lalu menyebar di pantai.

Jumlah, berat, dan panjang sampah di Pantai Motadikin dan Oetune yang berada di sebelah selatan Pulau Timor lebih sedikit dari kabupaten dan kota lainnya yang berada di 
sebelah utara Pulau Timor. Arus laut berperan penting dalam distribusi sampah (Hengstmann et al., 2017). Bulan Agustus merupakan waktu muson timur, yaitu angin yang mendorong arus laut bergerak dari Benua Australia menuju Benua Asia dan berhembus dari bagian timur ke arah barat (Kusumawati, 2016). Pergerakan upwelling pada Bulan Agustus di Selatan Pulau Timor (Pranowo, 2012) yang menyebabkan arus perairan mengalir menjauhi Pulau Timor (Gambar 8) diduga dapat menyebabkan sampah terbawa ke luar menjauhi Pulau Timor, sehingga bagian selatan Pulau Timor menjadi lebih bersih dibandingkan bagian utara. Walaupun jumlah potongan, berat, dan panjang sampah pada Pantai Motadikin dan Pantai Oetune merupakan yang terendah, namun masih adanya sampah yang terdampar di pantai menunjukkan masih kurangnya tingkat kesadaran pengunjung dalam menjaga kebersihan lingkungan dan kurangnya tempat sampah (Tabel 1) yang disediakan pengelola dibandingkan luas areal pantai. Pada bagian belakang pantai di kedua lokasi ini faktanya terdapat banyak sampah bertebaran di luar tempat sampah. Mengingat pentingnya peran arus laut yang dipicu oleh perubahan musim terhadap keberadaan dan penyebaran sampah di pesisir, maka musim atau bulan saat pengambilan data sampah di pesisir perlu dicantumkan.

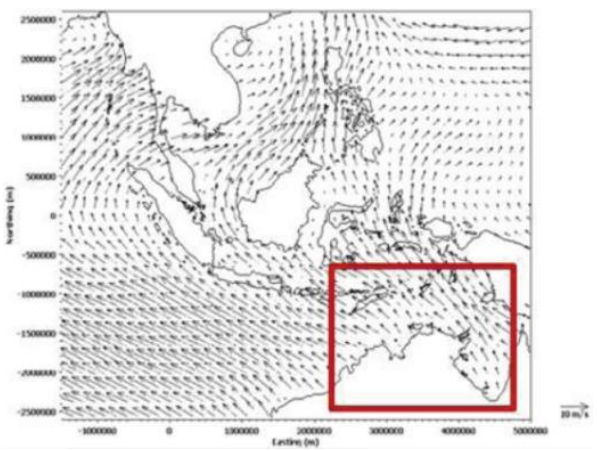

(a)

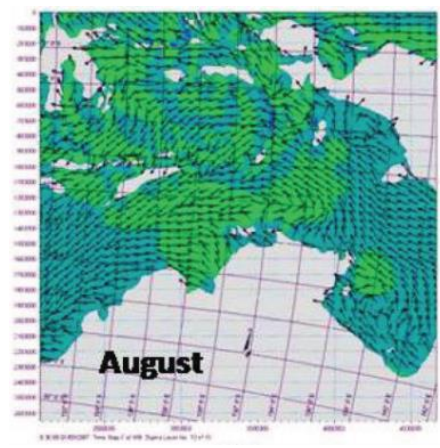

(b)

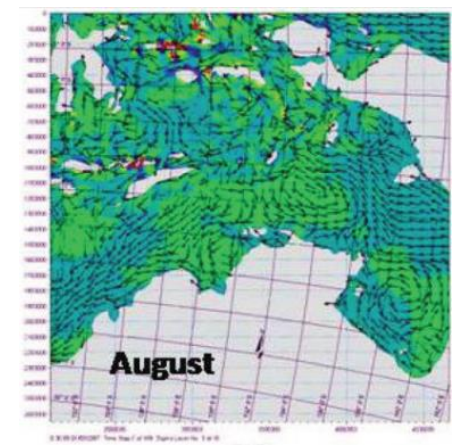

(c)

Sumber: Pranowo, 2012

Gambar 8. (a) Model Arah Angin 10 m, (b) Arus Sesaat, dan (c) Arus Rerata Pada Bulan Agustus

Berdasarkan dari kategori sampah yang ditemukan pada enam lokasi pantai, setidaknya terdapat tiga sumber sampah berdasarkan aktivitasnya. Sumber pertama adalah dari aktivitas rekreasi seperti sampah yang terkait dengan makanan dan minuman. Sumber kedua berasal dari aktivitas nelayan dan berlabuh. Sumber ketiga merupakan akibat tidak langsung atas kegiatan manusia, yaitu sampah yang dibawa oleh aliran arus sungai di sekitar lokasi wisata yang dihempaskan kembali ke darat dari laut atau sampah yang terbawa oleh arus laut sendiri dari lokasi yang jauh dari pantai. Pada kasus keenam pantai ini, sumber sampah dari aktivitas rekreasi sangat mencolok dibandingkan kedua sumber lainnya. Kajian ini menunjukkan bahwa manusia memberikan kontribusi yang besar terhadap timbulan sampah di pantai (Jayasiri et al., 2013). Tingginya persentase sampah plastik yang dihasilkan oleh pengunjung pantai memberikan informasi penting kepada pemerintah setempat sebagai pengambil kebijakan untuk segera bertindak dengan memberikan pemahaman dan penyadartahuan kepada masyarakat, baik melalui pendekatan adat sesuai budaya setempat maupun melalui peraturan yang tegas. Peran pengelola di setiap pantai wisata (Mestanza et al., 2019), baik dalam kegiatan bersih pantai, interaksinya dengan wisatawan agar tidak membuang sampah sembarangan, dan kerjasama dengan instansi lain seperti dinas yang berhubungan dengan kebersihan sangat penting dalam mereduksi sampah di pantai. Meskipun perubahan perilaku diri sendiri 
diyakini sebagai faktor utama dalam mereduksi sampah laut (Kusumawati, 2019), namun diperlukan peraturan dan sanksi yang tegas dari pemerintah sebagai regulator agar sampah dapat dikelola dengan baik (Jati, 2013).

Sosialisasi dan pelatihan pengelolaan serta pengolahan sampah diperlukan karena dapat meningkatkan pengetahuan, bereksplorasi dan berkreasi dalam menghasilkan benda bernilai guna baru, dapat membentuk komunitas yang peduli terhadap kebersihan lingkungan, dan aktif dalam menjaga kebersihan pantai. Aktivitas tersebut merupakan tindak nyata dalam upaya mengurangi sampah dan upaya penyelamatan pantai. Masingmasing pemerintah daerah dapat menjadikan data ini sebagai landasan kebijakan pengelolaan sampah laut sesuai yang tertuang pada Perpres No.83 Tahun 2018 (Peraturan Presiden Republik Indonesia, 2018). Kolaborasi antara pemerintah dan para stakeholder seperti instansi pendidikan dan Lembaga Swadaya Masyarakat perlu dilakukan agar sampah dapat dikurangi (reduce), digunakan kembali (reuse), dan didaur ulang (recycle), khususnya terhadap penggunaan material sekali pakai.

\section{Kesimpulan}

Penelitian cemaran sampah di pantai merupakan kegiatan yang tidak terpisahkan dari strategi pengelolaan limbah sesuai Rencana Aksi Nasional Penanganan Sampah Laut. Kajian ini menunjukkan sampah yang tidak terkelola tersebar pada seluruh pantai. Sumber sampah pada pantai berasal dari kegiatan rekreasi, aktivitas nelayan dan berlabuh, serta sampah antropogenik yang terbawa dari aliran sungai dan laut. Sampah plastik, khususnya yang merupakan wadah makanan dan minuman merupakan kategori sampah yang mendominasi pada seluruh pantai. Jumlah sampah pada bagian selatan Pulau Timor lebih rendah daripada bagian utara akibat adanya dinamika arus pada musim timur. Selain perubahan perilaku pada masyarakat, peran dan ketegasan pengelola dalam menata kebersihan pantai juga merupakan hal yang penting agar jumlah sampah di pantai dapat direduksi dan estetika pantai wisata dapat terjaga.

Data pada kajian ini memberikan gambaran sebaran sampah pantai yang mewakili masing-masing kabupaten dan kota di Pulau Timor, namun masih terdapat keterbatasan data sebaran sampah pada pantai lainnya yang secara spesifik tidak dikelola oleh pemerintah, baik yang dikelola oleh secara pribadi maupun yang tidak dikelola sama sekali. Perlu ada kajian menyeluruh terhadap pantai-pantai tersebut. Mengingat ada beberapa pantai yang dikelola oleh pemilik lahan karena mereka menganggap dirinya sebagai tuan tanah atas areal yang mereka kelola, maka pendekatan khusus diperlukan untuk memperoleh data sampah pada lokasi pantai tersebut.

\section{Ucapan Terima Kasih}

Penulis menyampaikan terima kasih kepada Fakultas Kelautan dan Perikanan, Universitas Nusa Cendana yang telah mendanai penelitian ini melalui DIPA Universitas Nusa Cendana Tahun 2020, MAK 525119, Kode kegiatan 4257.011 .053 sesuai dengan Surat Perintah Kerja (SPK) Kegiatan Penelitian Nomor:636/UN15.18.2/KU/2020. Penulis juga menghaturkan terimakasih kepada Ermin Yuliana Martis, Demianus Yorito Fallo, Rizky Bonbalan, Roberto A.Q. Jangga, dan Sarlin Sarlince Giri atas bantuannya selama kegiatan penelitian ini berlangsung.

\section{Daftar Pustaka}

Araújo, M. C. B., Silva-Cavalcanti, J. S., \& Costa, M. F. (2018). Anthropogenic litter on beaches with different 
levels of development and use: A snapshot of a coast in Pernambuco (Brazil). Frontiers in Marine Science, 5, 1-10. doi:10.3389/fmars.2018.00233.

Attamimi, A., Purba, N. P., Anggraini, S. R., Harahap, S. A., \& Husrin, S. (2015). Investigation of marine debris in Kuta Beach, Bali. The 1st Young Scientist International Conference of Water Resources Development and Environment Protection., C1-C7. Malang: Faculty of Engineering.

Aytan, U., Sahin, F. B. E., \& Karacan, F. (2019). Beach litter on Sarayköy Beach (SE Black Sea): Density, composition, possible sources and associated organisms. Turkish Journal of Fisheries and Aquatic Sciences, 20(2), 137-145. doi:10.4194/1303-2712-v20_2_06.

Badan Pusat Statistik (BPS) Provinsi Nusa Tenggara Timur. (2020). Provinsi Nusa Tenggara Timur dalam angka 2020. Kupang: BPS Provinsi Nusa Tenggara Timur.

Bangun, S. A., Sangari, J. R. R., Tilaar, F. F., Pratasik, S. B., Salaki, M. S., \& Pelle, W. (2019). Marine debris composition on Tasik Ria Beach, Tombariri, Minahasa Regency. Jurnal Ilmiah PLATAX, 71), 320-328. doi:10.35800/jip.7.1.2019.23411.

Cheshire, A. ., Adler, E., Barbière, J., Cohen, Y., Evans, S., Jarayabhand, S., .. Westphalen, G. (2009). UNEP/IOC guidelines on survey and monitoring of marine litter. In UNEP Regional Seas Reports and Studies, No. 186; IOC Technical Series. Nairobi: United Nations Environment Programme/Intergovernmental Oceanographic Commission.

Cordova, M. ., Nurhati, I. ., Riani, E., Nurhasanah, \& Iswari, M. . (2021). Unprecedented plastic-made personal protective equipment (PPE) debris in river outlets into Jakarta Bay during COVID-19 pandemic. Chemosphere, 268, 1-7. doi:10.1016/j.chemosphere.2020.129360.

Darmawi, A. (2017). Potensi timbulan sampah pada objek pariwisata baru di Kabupaten Bantul Yogyakarta. Jurnal Penelitian Teknologi Industri, 9(1), 61-71. doi:10.33749/jpti.v9i1.2907.

Evans, S. M., Dawson, M., Day, J., Frid, C. L. J., Gill, M. E., Pattisina, L. A., \& Porter, J. (1995). Domestic waste and TBT pollution in coastal areas of Ambon Island (Eastern Indonesia). Marine Pollution Bulletin, 30(2), 109-115. doi:10.1016/0025-326X(94)00182-9.

Fajriah, N., Fauzi, M., \& Sumiarsih, E. (2019). Composition and density of marine debris in the mangrove ecosystems of the Sungai Rawa Village, Sungai Apit Subsdistrict, Siak Regency, Riau Province. Asian Journal of Aquatic Sciences, 2(1), 29-38. doi:10.31258/ajoas.2.1.29-38.

Hengstmann, E., Gräwe, D., Tamminga, M., \& Fischer, E. K. (2017). Marine litter abundance and distribution on beaches on the Isle of Rügen considering the influence of exposition, morphology and recreational activities. Marine Pollution Bulletin, 115(1-2), 297-306. doi:10.1016/j.marpolbul.2016.12.026.

Jambeck, J. R., Geyer, R., Wilcox, C., Siegler, T. R., Perryman, M., Andrady, A., ... Law, K. L. (2015). Plastic waste inputs from land into the ocean. Science, 3476223), 768-771. doi:10.1126/science.1260352.

Jang, Y. C., Hong, S., Lee, J., Lee, M. J., \& Shim, W. J. (2014). Estimation of lost tourism revenue in Geoje Island from the 2011 marine debris pollution event in South Korea. Marine Pollution Bulletin, 81(1), 4954. doi:10.1016/j.marpolbul.2014.02.021.

Jati, D. R., \& Utomo, K. P. (2020). Identifikasi jenis dan jumlah sampah laut di Kabupaten Bengkayang dan Kota Singkawang. Jurnal Teknologi Lingkungan Lahan Basah, 8(1), 9-21. doi:10.26418/jtllb.v8i1.39900.

Jati, T. K. (2013). Peran pemerintah Boyolali dalam pengelolaan sampah lingkungan permukiman perkotaan (studi kasus: Perumahan Bumi Singkil Permai). Jurnal Wilayah dan Lingkungan, 1(1), 1-16. doi:10.14710/jwl.1.1.1-16.

Jayasiri, H. B., Purushothaman, C. S., \& Vennila, A. (2013). Quantitative analysis of plastic debris on recreational beaches in Mumbai, India. Marine Pollution Bulletin, 77(1-2), 107-112. doi:10.1016/j.marpolbul.2013.10.024.

Kato, M., Aoki-Suzuki, C., Nishiyama, T., Fushimi, E., \& Hotta, Y. (2019). G20 report on actions against marine plastic litter: First information sharing based on the G20 implementation framework. Japan: Ministry of the Environment Japan. Retrieved from Ministry of the Environment Japan website: https://www.iges.or.jp/en/pub/g20mpl2019/en.

Kementerian Lingkungan Hidup dan Kehutanan (KLHK). (2017). Pedoman pemantauan sampah pantai. Jakarta: Dirjen Pengendalian Pencemaran dan Kerusakan Pesisir dan Laut, Kementerian Lingkungan Hidup dan Kehutanan.

Kovač Viršek, M., Palatinus, A., Koren, Š., Peterlin, M., Horvat, P., \& Kržan, A. (2016). Protocol for microplastics sampling on the sea surface and sample analysis. Journal of Visualized Experiments: JoVE, 118, 1-9. 


\section{Sebaran Sampah Pantai di Pulau Timor, Nusa Tenggara Timur ...}

doi:10.3791/55161.

Krelling, A. P., Williams, A. T., \& Turra, A. (2017). Differences in perception and reaction of tourist groups to beach marine debris that can influence a loss of tourism revenue in coastal areas. Marine Policy, 85, 8799. doi:10.1016/j.marpol.2017.08.021.

Kusumawati, I. (2016). Pemodelan dinamika arus perairan Indonesia yang disebabkan oleh angin. Jurnal Perikanan Tropis, 3(1), 1-10. doi:10.35308/jpt.v3i1.31.

Kusumawati, I. (2019). Sampah laut tanggung jawab siapa? Studi kasus Kabupaten Aceh Barat. Jurnal Perikanan Tropis, 6(2), 69-75. doi:10.35308/jpt.v6i2.2183.

Kusumawati, I., Nasution, M. A., \& Alamsyah, A. (2019). Distribusi dan komposisi sampah laut pesisir di Kecamatan Kuala Pesisir Kabupaten Nagan Raya. Jurnal Laot IImu Kelautan, 1(1), 30-44. doi:10.35308/jlaot.v1i1.1073.

Kusumawati, I., \& Setyowati, M. (2018). Analisis faktor utama penumpukan sampah laut di Kabupaten Aceh Barat Daya. Jurnal of Aceh Aquatic Sciences, 2(1), 1-10. doi:10.35308/.v2i1.1683.

Kusumawati, I., Setyowati, M., \& Salena, I. Y. (2018). Identifikasi komposisi sampah laut di Pesisir Aceh Barat. Jurnal Perikanan Tropis, 5(1), 59-69. doi:10.35308/jpt.v5i1.1026.

Maharani, A., Purba, N. P., \& Faizal, I. (2018). Occurrence of beach debris in Tunda Island, Banten, Indonesia. E3S Web of Conferences, 47, 1-12. doi:10.1051/e3sconf/20184704006.

Marin, C. B., Niero, H., Zinnke, I., Pellizzetti, M. A., Santos, P. H., Rudolf, A. C., ... Polette, M. (2019). Marine debris and pollution indexes on the beaches of Santa Catarina State, Brazil. Regional Studies in Marine Science, 31, 100771. doi:10.1016/j.rsma.2019.100771.

Mestanza, C., Botero, C. M., Anfuso, G., Chica-Ruiz, J. A., Pranzini, E., \& Mooser, A. (2019). Beach litter in Ecuador and the Galapagos islands: A baseline to enhance environmental conservation and sustainable beach tourism. Marine Pollution Bulletin, 140, 573-578. doi:10.1016/j.marpolbul.2019.02.003.

Mrowiec, B. (2017). Plastic pollutants in water environment. Ochrona Srodowiska i Zasobow Naturalnych, 28(4), 51-55. doi:10.1515/oszn-2017-0030.

Nawastuti, D., \& Lewoema, Z. K. (2019). Identifikasi sampah laut bagi kesejahteraan masyarakat Desa Sinar Hading Kecamatan Lewolema Kabupaten Flores Timur. Jurnal Akrab Juara, 4(3), 1-13.

Pemerintah Republik Indonesia. (2008). Undang-Undang Nomor 18 Tahun 2008 tentang pengelolaan sampah. Jakarta.

Peraturan Presiden Republik Indonesia. (2017). Peraturan Presiden Nomor 97 Tahun 2017 tentang kebijakan dan strategi nasional pengelolaan sampah rumah tangga dan sampah sejenis sampah rumah tangga. Jakarta.

Peraturan Presiden Republik Indonesia. (2018). Peraturan Presiden Nomor 83 Tahun 2018 tentang penanganan sampah laut. Jakarta.

Portman, M. E., \& Brennan, R. E. (2017). Marine litter from beach-based sources: Case study of an Eastern Mediterranean coastal town. Waste Management, 69, 535-544. doi:10.1016/j.wasman.2017.07.040.

Pranowo, W. S. (2012). Dinamika upwelling dan down welling di Laut Arafura dan Timor. Widyariset, 15(2), 415-424.

Prevenios, M., Zeri, C., Tsangaris, C., Liubartseva, S., Fakiris, E., \& Papatheodorou, G. (2018). Beach litter dynamics on Mediterranean coasts: Distinguishing sources and pathways. Marine Pollution Bulletin, 129(2), 448-457. doi:10.1016/j.marpolbul.2017.10.013.

Purba, N. P., Ihsan, Y. N., Faizal, I., Handyman, D. I. W., Widiastuti, K. S., Mulyani, P. G., ... Hilmi, M. (2018). Distribution of macro debris in Savu Sea Marine National Park (Kupang, Rote, and Ndana Beaches), East Nusa Tenggara, Indonesia. World News of Natural Sciences, 21, 64-76.

Ribic, C. A., Sheavly, S. B., \& Klavitter, J. (2012). Baseline for beached marine debris on Sand Island, Midway Atoll. Marine Pollution Bulletin, 64(8), 1726-1729. doi:10.1016/j.marpolbul.2012.04.001.

Sahar, R. A., Rauf, A., \& Hamsiah, H. (2020). Pemetaan pola sebaran sampah berdasarkan jenis di Wilayah Pesisir Pantai Kuri Kabupaten Maros Sulawesi Selatan. Journal of Indonesian Tropical Fisheries (JointFish): Jurnal Akuakultur, Teknologi dan Manajemen Perikanan Tangkap, Ilmu Kelautan, 3(1), 89-100. doi:10.33096/joint-fish.v3i1.68.

Sarafraz, J., Rajabizadeh, M., \& Kamrani, E. (2016). The preliminary assessment of abundance and composition 
of marine beach debris in the northern Persian Gulf, Bandar Abbas City, Iran. Journal of the Marine Biological Association of the United Kingdom, 96(1), 131-135. doi:10.1017/S0025315415002076.

Schulz, M., van Loon, W., Fleet, D. M., Baggelaar, P., \& van der Meulen, E. (2017). OSPAR standard method and software for statistical analysis of beach litter data. Marine Pollution Bulletin, 122(1-2), 166-175. doi:10.1016/j.marpolbul.2017.06.045.

Shuker, I. G., \& Cadman, C. A. (2018). Indonesia - Marine debris hotspot rapid assessment: synthesis report. In The World Bank. Washington DC, USA: The World Bank.

Silmarita, S., Fauzi, M., \& Sumarsih, E. (2019). Composition and amount of marine debris in the mangrove area in Mengkapan Village, Sungai Apit District, Siak Regency, Riau Province. Asian Journal of Aquatic Sciences, 2(1), 49-56. doi:10.31258/ajoas.2.1.49-56.

Supardi, S., Hariyadi, S., \& Fahrudin, A. (2017). Analisis keberlanjutan pembangunan Kota Tepian Pantai (studi kasus: Kota Baubau Provinsi Sulawesi Tenggara). Jurnal Wilayah dan Lingkungan, 5(3), 188-204. doi:10.14710/jwl.5.3.188-204.

Syakti, A. D., Bouhroum, R., Hidayati, N. V., Koenawan, C. J., Boulkamh, A., Sulistyo, I., ... Wong-Wah-Chung, P. (2017). Beach macro-litter monitoring and floating microplastic in a coastal area of Indonesia. Marine Pollution Bulletin, 122(1-2), 217-225. doi:10.1016/j.marpolbul.2017.06.046.

Tahir, A., Werorilangi, S., Isman, F. M., Zulkarnaen, A., Massinai, A., \& Faizal, A. (2019). Short-term observation on marine debris at coastal areas of Takalar District and Makassar City, South Sulawesi-Indonesia. Jurnal IImu Kelautan SPERMONDE, 4(2), 48-53. doi:10.20956/jiks.v4i2.7061.

Tuhumury, N. C., \& Kaliky, I. (2019). Identifikasi sampah pesisir di Desa Rumah Tiga Kota Ambon. TRITON: Jurnal Manajemen Sumberdaya Perairan, 15(1), 30-39. doi:10.30598/TRITONvol15issue1page30-39.

Waileruny, W., Noija, D., Siahainenia, S. R., \& Matrutty, D. D. P. (2019). Hilangnya produksi dan pendapatan usaha penangkapan jaring insang akibat sampah di Teluk Ambon. In C. E. Waileruny, W.; Matrutty, D.D.P; Mailoa, M. N.; Hehanussa, K.; Pattipeilohy (Ed.), Prosiding Seminar Nasional Kelautan dan Perikanan 2019 Fakultas Perikanan dan Ilmu Kelautan Unpatti. Tema: Menakar Manfaat Eksploitasi Sumberdaya Kelautan dan Perikanan Maluku. Antisipasi Eksploitasi Gas Blok Masela dan Penetapan Maluku Sebagai Lumbung Ik (pp. 182-195). Ambon: Unpatti Press. doi:10.30598/semnaskp-18.

Watts, A. J. R., Porter, A., Hembrow, N., Sharpe, J., Galloway, T. S., \& Lewis, C. (2017). Through the sands of time: Beach litter trends from nine cleaned north cornish beaches. Environmental Pollution, 228, 416424. doi:10.1016/j.envpol.2017.05.016.

Willoughby, N. G. (1986). Man-made litter on the shores of the Thousand Island archipelago, Java. Marine Pollution Bulletin, 17(5), 224-228. doi:10.1016/0025-326X(86)90605-3. 